\title{
Analysis of Electropherogram Profile of Crude Cartilage Oligomeric Matrix Protein for Rheumatoid Arthritis Diagnosis
}

\author{
Nyi Mekar Saptarini ${ }^{1,3^{*}}$, Marlia Singgih Wibowo ${ }^{1}$, Ihsanawati ${ }^{2}$, Tutus Gusdinar ${ }^{1}$ \\ ${ }^{1}$ Department of Pharmacochemistry, School of Pharmacy Institut Teknologi Bandung, Jl Ganesha 10, West Java, 40132, Indonesia. \\ ${ }^{2}$ Department of Biochemistry, Faculty of Mathematic and Live Sciences, Institut Teknologi Bandung, Jl Ganesha 10, West Java, 40132, Indonesia. \\ ${ }^{3}$ Department of Pharmaceutical Analysis and Medicinal Chemistry, Faculty of Pharmacy, Universitas Padjadjaran, Jl Raya Bandung Sumedang km 21, \\ West Java, 45363, Indonesia.
}

\section{ARTICLE INFO}

Article history:

Received on: 04/08/2017

Accepted on: 12/10/2017

Available online: 30/12/2017

Key words:

Serum, Crude COMP,

Precipitation, Isoelectricp H,

SDS-PAGE.

\begin{abstract}
Cartilage oligomeric matrix protein (COMP) is a potential biomarker to monitor the development of cartilage damage and injury in rheumatoid arthritis (RA). The most accurate method of determining COMP levels is the enzyme-linked immunosorbent assay, but this method is expensive and requires trained analysts. An alternative method to solve this problem is analyzing the electropherogram profile of crude COMP. This method separates proteins based on molecular weight, so it can differentiate pentamer COMP from its fragments. This study was conducted to analyze the electroferogram profile of crude COMP of RA patients and normal individuals, so it can be applied to RA diagnosis. COMP was precipitated on its isoelectric $\mathrm{pH}$, then crude COMP was dissolved and electrophoresed by sodium dodecyl sulphate-polyacrylamide gel electrophoresis (SDS-PAGE).The electropherogram profiles of RA patients were dominated by pentamer and dimerbands, whereas the electropherogram profiles of normal individual were dominated by tetramer, trimer, and dimer bands. Increased pentamer COMP in serum was indicated by the cartilage damage. The electropherogram profile of crude COMP of RA patient can be differentiated from normal individuals, so it can be used for the RA diagnosis.
\end{abstract}

\section{INTRODUCTION}

Rheumatoid arthritis (RA) is a systemic autoimmune disease, characterized by erosive arthritis in symmetric synovial joints. This disease causes pain due to joint damage and dysfunction, decreased quality of life, and even disability (Schuna, 2007). The RA prevalence varies in different populations, generally $0.5-1.0 \%$ in the world (Sack et al., 2010) and $0.1-0.3 \%$ in Indonesia (Nainggolan, 2009). Epidemiological data suggest that genetic predisposition and exposure to unknown

* Corresponding Author

Nyi Mekar Saptarini, Jl Raya Bandung Sumedang km 21 Jatinangor,

West Java, Indonesia. E-mail: nyi.mekar @ unpad.ac.id

Phone: +62-8156078248 environmental factors play a role in RA triggering (Schuna, 2007). Early diagnosis and therapy in aggressive RA patients is essential to prevent disability due to late treatment (Vittecoq et al., 2003). Cartilage oligomeric matrix protein (COMP) is a secreted glycoprotein compound that found in extracelullar matrix of skeletal tissue (Holden et al., 2005). COMP determines the fiber composition of collagen type II in cartilage and in collaboration with other matrix proteins, to stabilize the collagen tissue (Halasz et al., 2007). The importance of this function was observed from the presence of COMP and its proteolytic fragments which released into synovial fluid and serum during skeletal dysplasia (Holden et al., 2001). So that COMP can be used as a potential biomarker to monitor the development of cartilage damage and During skeletal dysplasia, COMP and its proteolytic fragments were observed in synovial fluid and serum (Holden et al., 2001). 
This fact was supported the development of COMP as a biomarker to monitor the development of cartilage damage and injury (Vilim et al., 2002) and support the RA diagnosis (Tseng et al., 2009). The most accurate method of determining COMP levels is the enzyme-linked immunosorbent assay (ELISA), but this method is expensive and requires trained analysts. An alternative method to solve this problem is analysis electropherogram profile of crude COMP. The objective of this study was to analyze the electropherogram profile of crude COMP of RA patients and normal individuals, so it can be applied to RA diagnosis. This study was the first study that uses the crude COMP which is isolated from serum of RA patient and normal individuals then analyzed the electropherogram profile of crude COMP.

\section{MATERIALS AND METHODS}

\section{Subjects}

The study was conducted after being approved by Health Research Ethics Committee of Government Hospital of Dr. Hasan Sadikin Bandung, West Java, Indonesia, No. LB.04.01/A05/EC/075III/2016. The RA patients in Rheumatology Clinic and normal individuals were recruited after getting an explanation and signed the informed consent. This study was a follow-up study, all serum of RA patients and individuals normal were collected from previous studies (Saptarini et al., 2017).

\section{Materials}

All chemical reagents for buffer are of analytical grade (Merck). Acrylamide, N'N'-bis-methylene-acrylamide, glycerol, blue bromophenol, Tris-base, sodium dodecyl sulphate, N,N,N',N'tetramethylethenicaminamine, and ammonium persulfate are electrophoresis grade (Sigma Aldrich). Brilliant blue Coomassie R-250 and protein marker \# 26614 (Thermo Scientific).

\section{Precipitation of Serum COMP}

Precipitation of serum COMP was conducted by converting the serum $\mathrm{pH}$ to an isoelectric $\mathrm{pH}$ of COMP ( $\mathrm{pI} 4.36 \pm$ 0.01 ) using $0.1 \mathrm{M}$ citric acid solution $\mathrm{pH} 1.88 \pm 0.01$. The solution was centrifuged at $12,000 \mathrm{rpm}$ and $4{ }^{\circ} \mathrm{C}$, the precipitated COMP was separated from the supernatant. The precipitated COMP was reconstituted with citrate buffer $\mathrm{pH} 7.4 \pm 0.01$ and stored at -80 ${ }^{\circ} \mathrm{C}$.

\section{Electrophoresis of Crude COMP}

Analysis of electropherogram profile of crude COMP was conducted by electrophoresis using sodium dodecyl sulphatepolyacrylamide gel electrophoresis (SDS-PAGE) with separating gel of $10 \%$ polyacrylamide and retaining gel of 5\% polyacrylamide (Laemli, 1970). The electropherograms were scanned and analyzed by Gel Analyzer software. The bands on the electropherograms were marked and compared with protein marker. A plot of logarithmic molecular weight versus $\mathrm{Rf}$ was generated from the bands of proteins marker to determine the molecular weight of the unknown protein. If the curve is nearly linear, it can be described by the formula $y=m x+b$, where $y$ is the logarithmic molecular weight, $\mathrm{m}$ is the slope, $\mathrm{x}$ is the $\mathrm{Rf}$, and $\mathrm{b}$ is the y-intercept (http://www.gelanalyzer.com).

\section{Statistical Analysis}

Statistical analyzes were conducted by $\mathrm{R}$ i386 3.2.0 software for Windows under license from the GNU General Public License (http://cran.r-project.org). The electropherogram profile was grouped based on the bands composition, then analysis of variance was performed to the electropherogram profile groups against COMP levels of serum and crude COMP. The statistically significant difference was expressed if $p<0.05$.

\section{RESULTS AND DISCUSSION}

\section{Precipitation of Serum COMP}

Eight normal individual serum (code P5 - P12) could not be used for partial purification, because of a little volume of serum. COMP will precipitate at its isoelectric point (pI $4.36 \pm$ 0.01). At isoelectric points, proteins have a zero net charge, so the electrostatic repulsion between protein molecules is gone which lead to aggregates formation (Harrison et al., 2015). Weak and dilute acid ( $0.1 \mathrm{M}$ citric acid solution) was used to achieve the isoelectric point. It was because weak or dilute acids minimize hydrolysis and denaturation, but still made the aggregates. Protein precipitation is used to concentrate and purify proteins from various contaminants (Harrison et al., 2015). COMP precipitation was accelerated by centrifugation. The colour of crude COMP was whitish bone. After the filtrate was decanted, the crude COMP was reconstituted with phosphate buffer.

\section{Electrophoresis of Crude COMP}

Protein and sodium dodecyl sulfate form an anionic complex with a constant negative charge per unit mass. This results in the electrophoresis separation in polyacrylamide gel depending on the protein molecular weight. There is a linear relationship between the logarithm of molecular weight and the relative migration distance of the protein-SDS complex. Trisglycine buffer systems separate proteins with high $\mathrm{pH}$, thus minimize the protein aggregation and make a good separation (Garfin, 2009). The electropherogram profile of RA patients (Fig. 1) and normal individuals (Fig. 2) showed the presence of bands with molecular weights bigger than $200 \mathrm{kDa}$ with various intensities. These bands were predicted as a pentamer form of COMP. The intensity of these band was proportional to COMP level in crude COMP. The higher the COMP level, the darker the band intensity. COMP levels in the crude COMP have been determined (Saptarini et al., 2017). The electropherogram of two RA patients without disease-modifying antirheumatic drugs (DMARDs), i.e. RP23 and RL27, were different from the RA patient electroferogram with prescribed DMARDs. DMARDs, such as methotrexate, was proven to modify the development of joint damage (Lindqvist et al., 2005), which resulting decreased COMP levels along with improved joints condition in RA patients. 
The RP23 electropherogram showed that pentamer form more than tetramer form of COMP. The RL27 electropherogram showed that tetramer form more than pentamer form of COMP. The difference in electropherogram profile may be due to disease duration of RP23 (12 months) are longer than RL27 (3 months) and COMP level of RP23 $(22.78 \mu \mathrm{g} / \mathrm{mL})$ higher than RL27 $(16.53 \mu \mathrm{g} / \mathrm{mL})$.

Image analysis software allows easy and fast protein analysis. Gel Analyzer software was used to create all graphs from electropherogram, then determine the equation (Table 1). Each equation was used to estimate the unknown protein molecular weight on each band. Estimated protein volume can be determined by comparing the band intensity of the sample to the protein marker. All samples (RA patients and normal individuals) had proteins with molecular weights ranging from 54 to $60 \mathrm{kDa}$ which estimated as fragments of the degraded COMP (Fig. 3). COMP levels were estimated to be comparable to the tetramer and pentamer forms of COMP, due to the limitation of capture antibodies in ELISA kits, i.e. mouse anti-COMP monoclonal antibody, which do not react with monomer, dimer, or trimer forms of COMP. Specific electropherogram profiles can be used to differentiate crude COMP of RA patients from normal individuals. Electropherogram of RA patients were dominated by pentamer and dimer bands, whereas electropherograms of normal individuals were dominated by tetramer, trimer, and dimer bands (Table 2). COMP was found in pentamer and its fragments. This was consistent with the literature that COMP and its proteolytic fragments were released into synovial fluid and serum (Holden et al., 2001). The electropherogram profile based on the band composition were categorized into four groups for RA patients and six groups for normal individuals (Table 3). Analysis of variance in each RA patient group showed no significant difference with COMP level of serum $(p=0.56)$ and crude COMP $(p=0.28)$. It was the same results for normal individuals, i.e no significant difference with COMP levels of serum $(p=0.59)$ and crude COMP $(p=0.32)$. Analysis of variance the electropherogram profile group of RA patients and normal individuals showed significant difference in COMP levels of crude COMP $(p=0.55 \mathrm{x}$ $10^{-3}$ ). It was showed that the electropherogram profile of RA patients can be differentiated from normal individuals, because of the different distribution of COMP oligomers between RA patients and normal individuals.

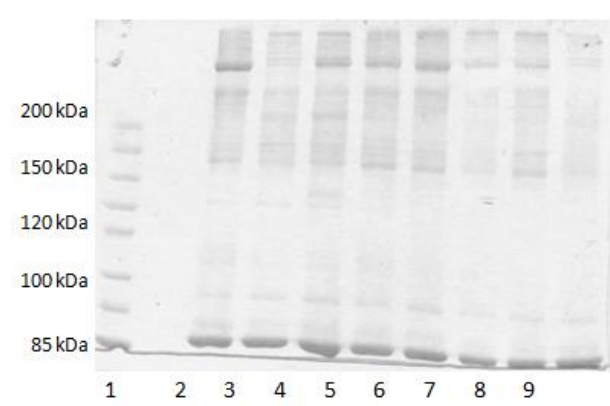

(a)

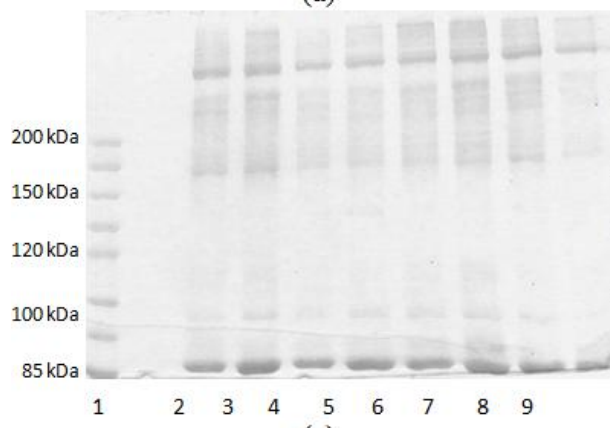

(c)

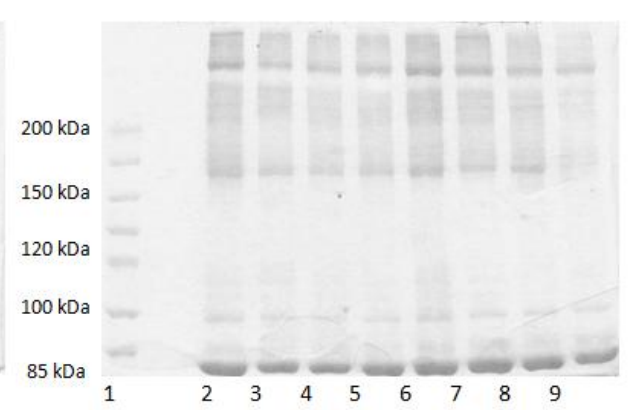

(b)

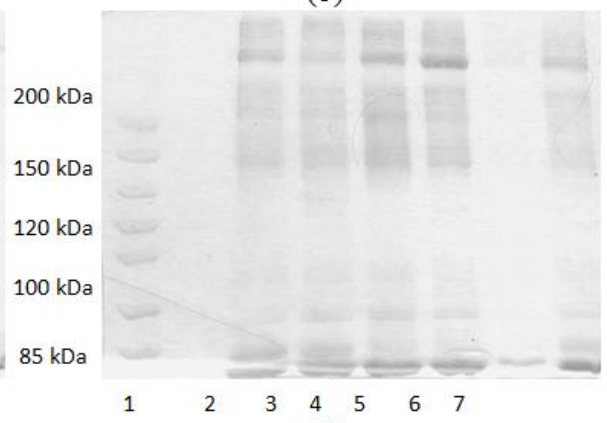

(d)

Fig. 1: Electropherogram profile of RA patients. (a) code RL1-RP8: Lane 1= marker, 2=RL1, 3=RP2, 4= RL3, 5= RP4, 6= RP5, 7= RP6, 8= RP7, 9= RP8. (b) codeRL9-RP16. Lane 1= marker, 2= RL9, 3=RP10, 4= RL11, 5=RP12, 6=RP13, 7=RP14, 8=RP15, 9= RP16. (c) code RP17-RP24. Lane 1= marker, 2= RP17, 3= RP18, 4= RP19, 5= RP20, 6= RP21, 7= RP22, 8= RP23, 9= RP24. (d) code RP25-RP30. Lane 1= marker, 2= RP25, 3= RP26, 4= RL27, 5= RP28, 6= $\mathrm{RP} 29,7=\mathrm{RP} 30 . \mathrm{R}=\mathrm{RA}$ patient, $\mathrm{P}=$ female, $\mathrm{L}=$ male.

Table 1: Equation of electropherogram of RA patients and normal individuals.

\begin{tabular}{|c|c|c|c|}
\hline Subject & Subject code* & Equation of marker protein & Linearity $\left(\mathbf{R}^{2}\right)$ \\
\hline \multirow{2}{*}{ RA patient } & RL1-RP8 & $\mathrm{y}=667.01 \times 10^{-4.53 \mathrm{x}}+47.12$ & 0.994 \\
\hline & RL9 - RP16 & $y=762.24 \times 10^{-4.75 x}+47.65$ & 0.994 \\
\hline \multirow{3}{*}{ Normal individual } & $\mathrm{P} 1-\mathrm{P} 16$ & $y=948.67 \times 10^{-5.34 x}+50.01$ & 0.993 \\
\hline & $\mathrm{P} 17-\mathrm{P} 24$ & $y=480.83 \times 10^{-3.84 x}+42.58$ & 0.997 \\
\hline & P25 - L30 & $y=558.74 \times 10^{-4.07 x}+40.88$ & 0.992 \\
\hline
\end{tabular}

* $\mathrm{R}=\mathrm{RA}$ patient, $\mathrm{P}=$ female, $\mathrm{L}=$ male. 


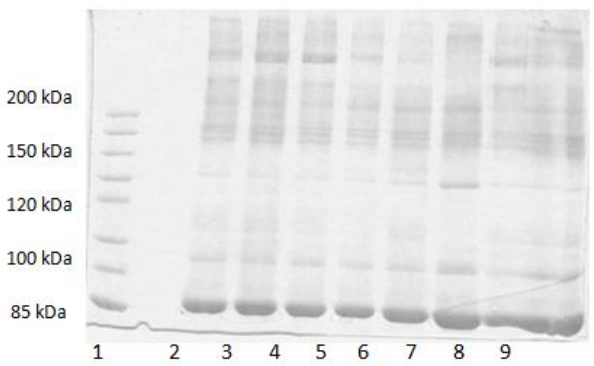

(a)

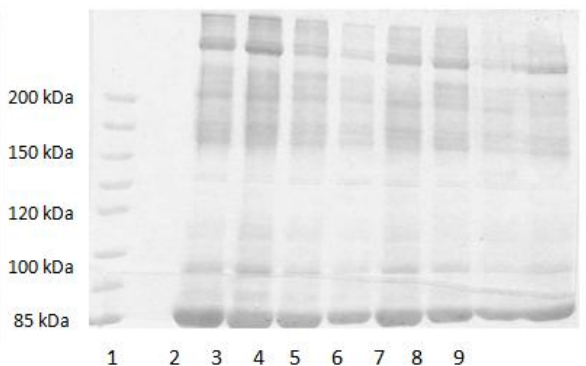

(b)

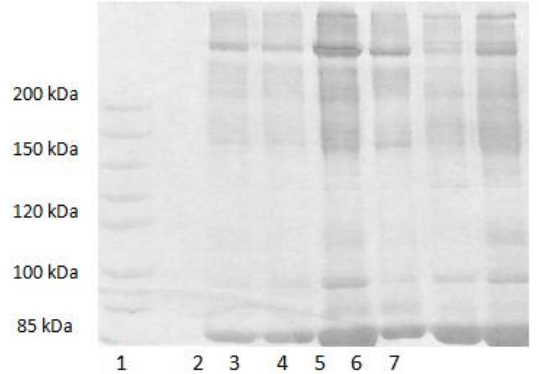

(c)

Fig. 2: Electropherogram profile of normal individuals (a) code $\mathrm{P} 1-\mathrm{P} 16$. Lane $1=$ marker, $2=\mathrm{P} 1,3=\mathrm{P} 2,4=\mathrm{P} 3,5=\mathrm{P} 4,6=\mathrm{P} 13,7=\mathrm{L} 14,8=\mathrm{P} 15,9=\mathrm{P} 16$. (b) code P17-P24. Lane 1= marker, 2= P17, 3= L18, 4= P19, 5= L20, 6= P21, 7= L22, 8= P23, 9= P24. (c) code P25-L30.Lane 1= marker, 2= P25, 3= P26, 4= P27, 5= $\mathrm{P} 28,6=\mathrm{P} 29,7=\mathrm{L} 30 . \mathrm{P}=$ female, $\mathrm{P}=$ male.

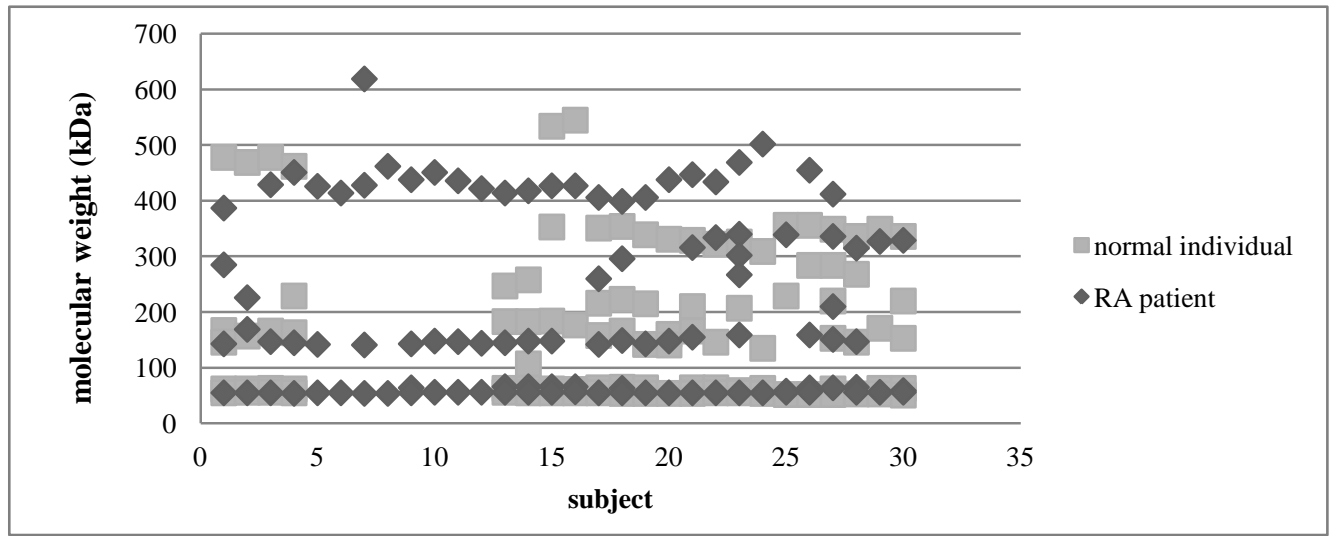

Fig. 3: Distribution of estimated protein molecular weight of crude COMP in RA patients and normal individuals.

Table 2: Distribution of estimated COMP forms in the samples.

\begin{tabular}{|c|c|c|c|}
\hline \multirow[t]{2}{*}{ Estimated COMP form } & \multirow[t]{2}{*}{ Molecular weight (kDa) } & \multicolumn{2}{|c|}{ Percentage (\%) } \\
\hline & & RA patient & Normal individual \\
\hline Monomer fragment & $54-60$ & 100.0 & 100.0 \\
\hline Dimer & $141-184$ & 73.3 & 68.2 \\
\hline Trimer & $207-284$ & 20.0 & 59.2 \\
\hline Tetramer & $302-362$ & 13.3 & 68.2 \\
\hline Pentamer & $387-478$ & 96.7 & 22.7 \\
\hline
\end{tabular}

Table 3: The subject groups based on the bands composition.

\begin{tabular}{|c|c|c|c|}
\hline Subject & Groups based on the bands composition & Number of subject (n) & Subject code* \\
\hline \multirow{4}{*}{ RA patient } & Penta-, monomer & 7 & RP6, RP8, RP16, RP24, RP25, RP29, RP30 \\
\hline & Penta-, di-, monomer & 16 & $\begin{array}{c}\text { RL3, RP4, RP5, RP7, RP7, RL9, RP10, RP11, RP12, RP13, RP14, } \\
\text { RP15, RP19, RP20, RP21, RP26, RP28 }\end{array}$ \\
\hline & Penta-, tri-, di-, monomer & 3 & RL1, RP17, RP18 \\
\hline & Irregular & 4 & RP2, RP22, RP23, RP27 \\
\hline \multirow{6}{*}{$\begin{array}{c}\text { Normal } \\
\text { individual }\end{array}$} & Penta-, di-, monomer & 4 & $\mathrm{P} 1, \mathrm{P} 2, \mathrm{P} 3, \mathrm{P} 16$ \\
\hline & Tetra-, tri-, di-, monomer & 6 & P17, L18, P21, P27, P28, L30 \\
\hline & Tetra-, tri-, monomer & 3 & $\mathrm{P} 23, \mathrm{P} 25, \mathrm{P} 26$ \\
\hline & Tetra-, di-, monomer & 4 & L20, P22, P24, P29 \\
\hline & Tri-, di-, monomer & 3 & P13, L14, P19 \\
\hline & Irregular & 2 & $\mathrm{P} 4, \mathrm{P} 15$ \\
\hline
\end{tabular}

* $\mathrm{R}=\mathrm{RA}$ patient, $\mathrm{P}=$ female, $\mathrm{L}=$ male. 


\section{CONCLUSION}

The electropherogram profile of crude COMP of RA patient can be differentiated from normal individuals, so it can be used for the RA diagnosis.

Financial support and sponsorship: Nil.

Conflict of Interests: There are no conflicts of interest.

\section{REFERENCES}

Garfin DE. One-dimensional gel electrophoresis. Methods in Enzymology, 2009; 463: 497-513.

Halasz K, Kassner A, Morgelin M, Heinegard D. COMP Acts as a Catalyst in Collagen Fibrillogenesis. J Biol Chem, 2007; 282: 3116673.

Harrison RG, Todd PW, Rudge SR, Petrides DP. 2015. Bioseparations Science and Engineering. 2nd ed. NY: Oxford University Press, p. 577.

Holden P, Holden P, Keene DR, Lunstrum GP, Bachinger HP, Horton WA. Secretion of Cartilage Oligomeric Matrix Protein Is Affected by the Signal Peptide. J Biol Chem, 2005; 280 (17): 17172-79.

Holden P, Meadows R, Chapman K, Grant M, Kadler K, Briggs M. Cartilage Oligomeric Matrix Protein Interacts with Type IX Collagen, dan Disruptions to These Interactions Identify A Pathogenetic Mechanism In A Bone Dysplasia Family. J Biol Chem, 2001; 276: 6046-55.

Laemli UK. Cleavage on structural proteins during the assembly of the head of bacteriophage T4. Nature, 1970; 227: 680-85.

Lindqvist E, Eberhardt K, Bendtzen K, Heinegård D, Saxne T. Prognostic laboratory markers of joint damage in rheumatoid arthritis. Ann Rheum Dis, 2005;64(2):196-201.

Nainggolan O. Prevalensi dan determinan penyakit rematik di Indonesia. Majalah Kedokteran Indonesia, 2009; 59 (12): 588-94.
Sacks JJ, Luo YH, Helmick CG. Prevelence of Specific Types of Arthritis dan Other Rheumatic Conditions in The Ambulatory Health Care System in The United States 2001-2005, Arthritis Care Res (Hoboken), 2010; 62 (4): 460-64.

Saptarini NM, Pratiwi DE, Febrina E, Singgih MW, Gusdinar T. Correlation Study Of Disease Activity Score And Serum Cartilage Oligomeric Matrix Protein Level Of Rheumatoid Arthritis Patients In Bandung, Indonesia. Asian J Pharm and Clin Res, 2017; 10 (1): 290-93.

Schuna AA. 2007. Rheumatoid Arthritis in Pharmacotherapy: A Pathophysiologic Approach. 7 ed. Dipiro JT, Talbert RL, Yee GC, Matzke GR, Wells BG, Posey LM. (eds). Singapore: Mc Graw Hill Medical, 1538-46.

Tseng S, Reddi AH, DiCesare PE. Cartilage Oligomeric Matrix Protein (COMP): A Biomarker of Arthritis. Biomarker Insights, 2009; 4: 33-44.

Vilim V, Olejarova M, Machacek S, AlE. Serum Levels of Cartilage Oligomeric Matrix Protein (COMP) Correlate with Radiographic progression of Knee Osteoarthritis.Osteoarthritis Cartilage, 2002; 10; 707 13.

Vittecoq O, Pouplin S, Krzanowska K, Jouen-Beadem F, Me'nard JF, Gayet A, Daragon A, Tron F, Loet XL. Rheumatoid Factor is The Strongest Predictor of Radiological Progression of Rheumatoid Arthritis in A Three-Year Prospective Study in Community-Recruited Patients. Rheumatology, 2003; 42: 939-46.

\section{How to cite this article:}

Saptarini NM, Wibowo MS, Ihsanawati, Gusdinar T. Analysis of Electropherogram Profile of Crude Cartilage Oligomeric Matrix Protein for Rheumatoid Arthritis Diagnosis. J App Pharm Sci, 2017; 7 (12): 151-155. 